\title{
A Maastrichtian microbial reef and associated limestones in the Roca Formation of Patagonia (Neuquén Province, Argentina)
}

\author{
Wolfgang Kiessling ${ }^{*}, 1$, Roberto Scasso ${ }^{2}$, Martin Aberhan ${ }^{1}$, Lucas Ruiz $^{2}$ \& Sven Weidemeyer ${ }^{1}$ \\ ${ }^{1}$ Museum für Naturkunde der Humboldt-Universität zu Berlin, Invalidenstraße 43, D-10115 Berlin, Germany \\ ${ }^{2}$ Departamento de Ciencias Geológicas, FCEN, Universidad de Buenos Aires, Ciudad Universitaria, Pab. 2, $1^{\circ}$ Piso, \\ 1428 Buenos Aires, Argentina
}

Received 5 January 2006, accepted 25 February 2006

Published online 17 July 2006

With 9 figures, 1 table

Key words: microbial reefs, microfacies, Maastrichtian, paleoclimate, Patagonia.

\begin{abstract}
We describe a small microbial reef and associated limestones occurring in a Maastrichtian transgressive succession of mixed carbonate-siliciclastic lithologies at Sierra Huantraico near Chos Malal (Neuquén, Argentina). Strontium isotope data suggest that the reef is of earliest Maastrichtian age. The small reef $(0.8 \mathrm{~m}$ thick, $2 \mathrm{~m}$ wide) is mostly composed of peloidal bindstone, dense stromatolite-cement crusts and thrombolite. Except for some ostracods, no metazoan fossils were found in the reef structure, although the majority of peloids are fecal pellets, probably of larger crustaceans. Small foraminifers with calcite tests and probable green algae have also been noted. Sedimentological data and fossils within and immediately above the reef suggest that the reef was formed in a transgressive systems tract under freshwater to brackish-water conditions. Limestones above the reef are serpulid-bryozoan packstones and intraclast-ooid grainstones. These limestones yield a mixture of typical non-tropical (common serpulids and bryozoans) and typical tropical aspects (common dasycladaceans and ooids). This mosaic is explained by salinity fluctuations, which in our case dominate over temperature in determining the grain associations.
\end{abstract}

Schlïsselwörter: mikrobielles Riff, Mikrofazies, Maastrichtium, Paläoklima, Patagonien.

\section{Zusammenfassung}

Wir beschreiben ein kleines mikrobielles Riff, das in der Sierra Hunatraico (Neuquén, Argentinien) in einer transgressiven, gemischt siliziklastisch-kalkigen Abfolge gefunden wurde. Nach Strontiumisotopen-Datierung ist das Riff in das unterste Maastrichtium zu stellen. Das kleine Riff (0,8 m Mächtigkeit, $2 \mathrm{~m}$ Breite) besteht überwiegend aus peloidalem Bindstone, dichten Stromatolith-Zement-Krusten und Thrombolith. Mit Ausnahme von Ostrakoden konnten keine Metazoen in der Riffstruktur nachgewiesen werden, obwohl die Mehrzahl der Peloide als Kotpillen zu interpretieren sind, die vermutlich auf größere Krebse zurückgehen. Kleine Foraminiferen und mögliche Grünalgen sind die einzigen zusätzlich nachweisbaren Eukaryoten. Die Fossilien im Riff und in den überlagernden Kalken sprechen für ein Riffwachstum unter transgressiven aber hyposalinen Bedingungen. Die Kalke über dem Riff tragen ein gemischtes paläoklimatisches Signal, das sowohl typisch nicht-tropische als auch typisch tropische Komponenten beinhaltet. Dieses Mosaik ist möglicherweise durch die starken Salinitätsschwankungen erklärbar und erfordert ein Überdenken der bisherigen Modelle zur klimatischen Steuerung der Karbonatsedimentation.

\section{Introduction and background}

Reefal microbial carbonate production shows a gradual decrease through the Phanerozoic (Kiess- ling 2002; Riding 2004). The late Mesozoic and Cenozoic are times from when microbial carbonates in normal marine settings are particularly rarely reported. An analysis of the PaleoReefs

\footnotetext{
* Corresponding author: e-mail: wolfgang.kiessling@museum.hu-berlin.de
} 
database (Kiessling \& Flügel 2002) shows the long-term decline of microbial reefs during the Phanerozoic (Fig. 1). Superimposed on the longterm trend, however, are semi-cyclic fluctuations with pronounced peaks in (1) the CambrianEarly Ordovician, (2) latest Devonian to Late Carboniferous, and (3) Late Permian to Middle Triassic. The Cretaceous through Neogene are times when marine reefal microbial carbonate production was apparently very low. Especially scarce are pure microbial reefs, which lack any contribution of calcareous algae or skeletal metazoans to reef construction. Although occurrences of microbial carbonates of latest Cretaceous and Cenozoic age are increasingly noted, most examples stem from lacustrine settings (Kadolsky \& Koch 1988; Rouchy et al. 1993; Arp 1995; Camoin et al. 1997; Pache et al. 2001). In addition to the famous stromatolitic buildups in the hypersaline Hamelin Pool at Shark Bay/Australia (Reid et al. 2003), microbial buildups are becoming increasingly known in a variety of modern environments (Feldmann \& McKenzie 1998; Laval et al. 2000; Arp et al. 2003; Gautret et al. 2004; Reitner et al. 2005). This suggests that reefal microbial carbonates may be more common than usually reported.

Here we describe a small Maastrichtian microbial reef and associated limestone facies occurring in the basal Roca Formation (Malargüe Group) of the Neuquén Basin of Argentina. We focus on the description of this reef structure and discuss its environmental setting. The overlying limestones are also described in some detail, because their grain associations add to the ongoing discussion of temperature versus salinity control of the composition of ancient limestones.

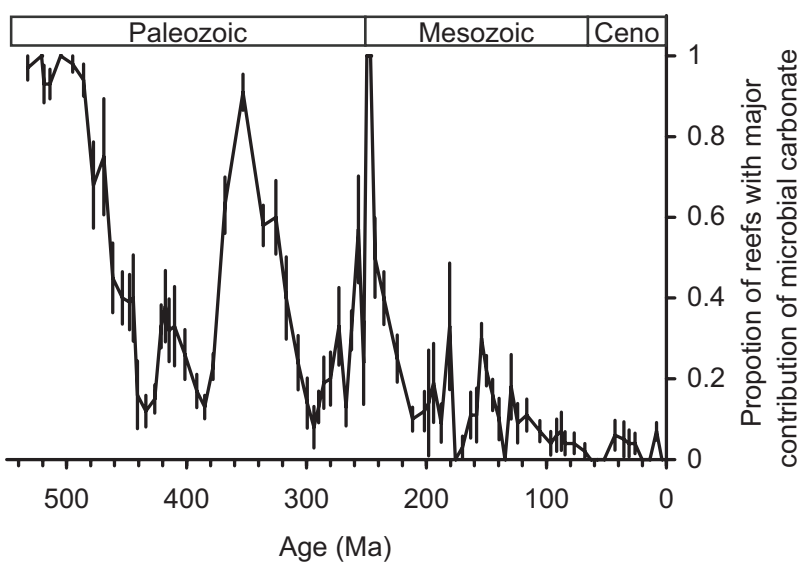

Fig. 1. Phanerozoic microbial reefs. Proportion of reefs in which microbial carbonates are reported to be volumetrically major constituents. Stratigraphic resolution is to the stage and epic level. The plot includes reefs in marginal marine settings but excludes reefs in lakes. Error bars demarcate one standard error in each direction.

\section{Methods}

We applied field studies, paleontological investigations of bivalves and microfacies analyses of thin sections. We have analyzed eleven thin sections of the reef structure and six thin sections from the overlying limestones. Selected well preserved calcitic shell material was measured for ${ }^{87} \mathrm{Sr} /{ }^{86} \mathrm{Sr}$ ratios for an age assignment. Due to the very limited sample size (only the best-preserved pieces of original shell material were measured), chemical tests of diagenetic alteration could not be performed. Samples were measured at the Bochum isotope laboratory on a Finnigan MAT 262 thermal-ionization mass spectrometer. The raw ${ }^{87} \mathrm{Sr} /{ }^{86} \mathrm{Sr}$ ratios of samples are adjusted by $29 \times 10^{-6}$ to a value of 0.709175 of USGS EN-1, to derive numerical ages from the look-up table of McArthur et al. (pers. comm. 2005)

Diversity and evenness of bivalve assemblages is reported applying the Shannon-Wiener index $H=-\sum p_{i} \ln p_{i}$ where $p_{i}$ is the proportion of the $i_{\text {th }}$ species in the faunal assemblage and Pielou's evenness $J=\mathrm{H}^{\prime} / \ln S$, where $S$ is the number of species. The description of microbial fabrics follows Riding (2000) and other descriptive terms of limestones rely on Flügel (2004).

\section{Geological setting and stratigraphic section}

The study area is situated in the Sierra Huantraico, one of the key areas of Late Cretaceous-Paleocene sedimentation in the Neuquén Basin (Bertels 1975; Barrio 1990). We have measured two sections in the northwestern part of the geological map Hoja 33c "Los Chihuidos Norte" (Ramos 1981), north of Cerro Villegas, to the southwest of the Ruta Provincial 36 (Fig. 2). The studied beds belong to the Roca Fm. (sensu Ramos 1981), which together with the Loncoche Fm. makes up the lower part the late Campanian-Paleocene Malargüe Group (Digregorio \& Uliana 1980). The Malargüe group reaches a thickness of nearly $300 \mathrm{~m}$ in the area; it consists of mixed carbonate-siliciclastic lithologies and evaporites. A semi-arid climate is thought to have favored this facies association (Barrio 1990). Weaver (1927) and Camacho (1968) studied the molluscan fauna of the Roca Fm. and equivalent units in the area of the present study and assigned a Maastrichtian-Danian age to the succession.

According to Ramos (1981), only two formations within the Malargüe Group should be present in the area: the Loncoche Formation at the base and the Roca Formation at the top. In contrast, Barrio (1990) has distinguished two formations above the Loncoche Formation, the Jagüel Formation and the Roca Formation. We have not seen the calcareous mudstones typical of the Jagüel Fm. in our sections (they are probably covered by scree) and thus follow the subdivision 

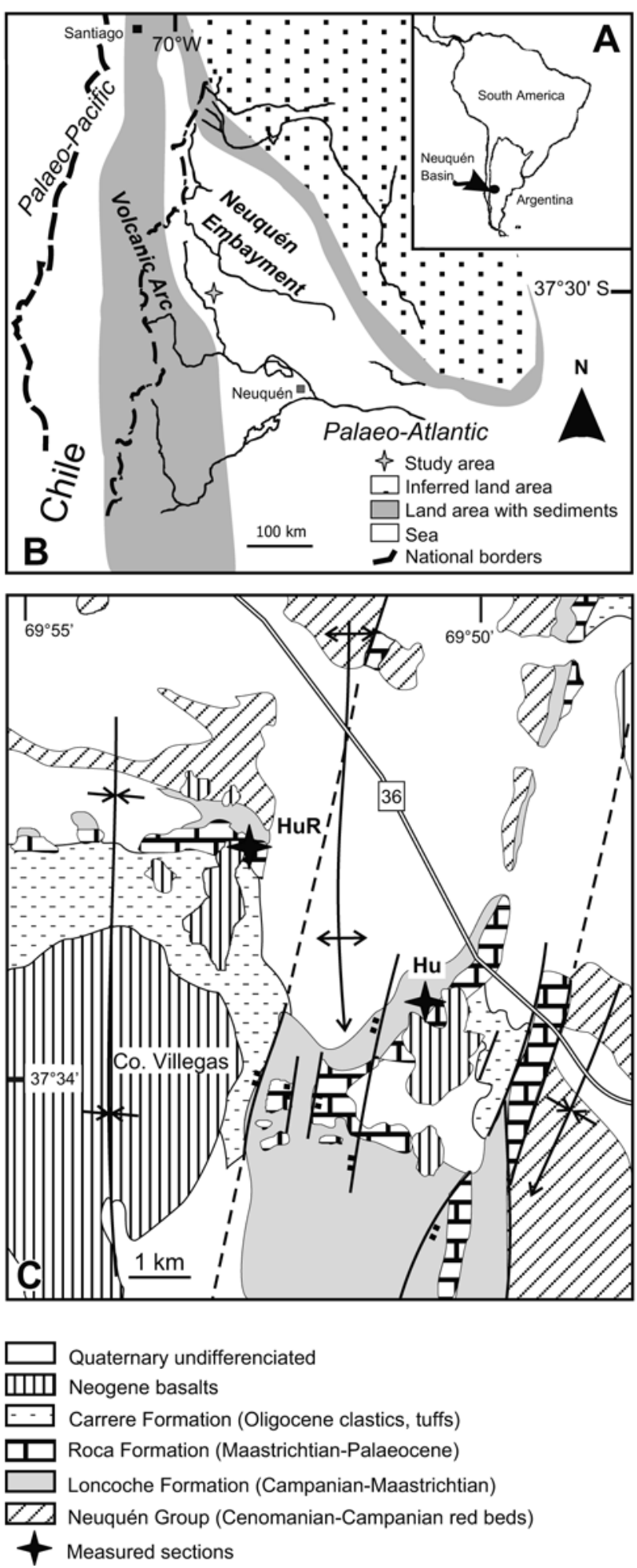

Fig. 2. Location map of the study area. $\mathbf{A}$ - location map of the Neuquén Basin; $\mathbf{B}$-Palaeogeographic setting of the Neuquén Basin in the latest Cretaceous-earliest Paleocene; C - Simplified geological map (modified after Ramos, 1981) and position of our sections.

of Ramos (1981). The Loncoche Formation (an equivalent to the Allen Fm. exposed to the east) consists of claystones, siltstones, and marls with isolated gypsum beds and is locally well exposed.
The sediments of the Loncoche Fm. are usually interpreted as lacustrine deposits, but others favor a tide-dominated estuarine environment (Barrio 1990, 1991; Parma \& Casadio 2005). The basal Roca Fm., exposed in the lower part of our sections, does not show the carbonate-dominated lithologies typical of the formation (Weaver 1927). Rather, fine-grained to coarse-grained sandstones prevail (Fig. 3), which may have led to confusion in lithostratigraphic assignments. Although bioclastic limestone beds are common in this basal member (Roca Fm. s.l.), the typical carbonate-dominated sedimentation of the Roca Fm. (s. str.) starts much higher in the investigated sections. The base of this upper member roughly corresponds to the Cretaceous-Paleogene boundary, based on microfossils (Bertels 1968, 1969a, 1969b, 1970) and bivalves (Camacho 1968).

Two parallel sections were measured in the Huantraico area spanning the Cretaceous-Paleogene boundary (Fig. 2C). The reference section is abbreviated $\mathrm{Hu}$ and the reef-bearing section is named HuR (Fig. 3). In HuR medium-grained sandstones and cross-bedded (some tabular but mostly trough cross-bedding) conglomerates dominate in the basal portion below the reef. The only fossils seen in this interval are ostracods and gastropods, which are often enriched in coquinas. Bioturbation was not observed. This part of the section probably corresponds to the base of the Roca Formation (sensu Ramos 1981). Due to poor exposure, we cannot use a wide range of sedimentary structures for the environmental interpretation. However, an estuarine environment appears to be most likely (Barrio 1991).

The sediments above the reef are carbonate packstones and grainstones with abundant serpulids followed by fine-grained to coarse-grained sandstones with some limestone and thin mudstone intercalations. The common macrofauna in the sandstones and mudstones consists of marine molluscs and yields highly diverse bivalve associations (Average of 10 collections: ShannonWiener index $\mathrm{H}=2.1$, Evenness $\mathrm{J}=0.84$ ) indicative of normal marine conditions. This interpretation is also supported by common echinoids.

As we did not perform micropaleontological studies, age-diagnostic fossils are rare, especially in the lower portion of the sections. The lower to middle Roca Formation contains assemblages rich in Amphidonte mendozana (Ihering), Camptochlamys mahuidaensis (Weaver), Pseudolimea angusta (Camacho), Pterotrigonia windhauseniana (Wilckens) and Pycnodonte vesicularis (La- 


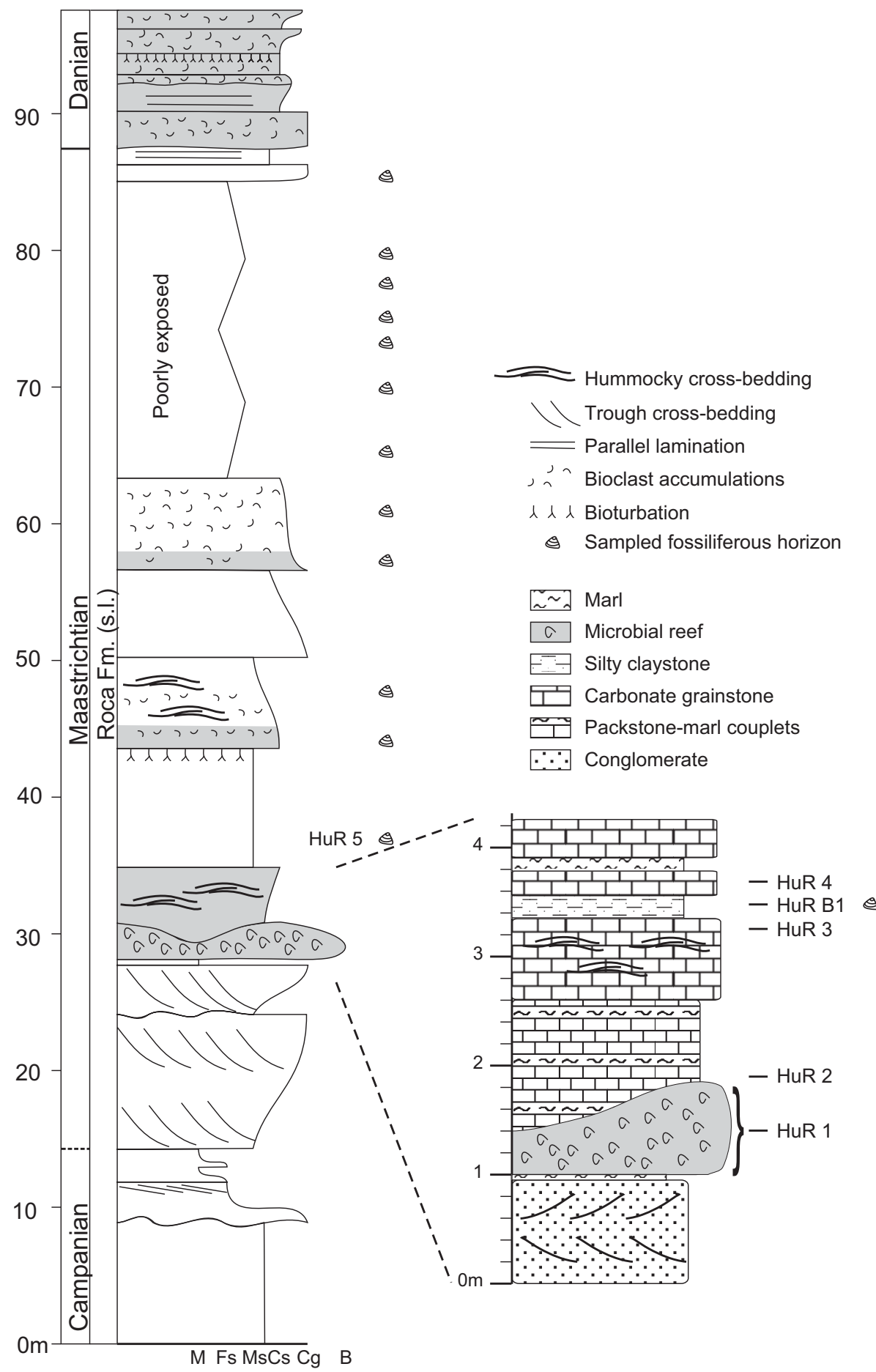

Fig. 3. Schematic lithologic section at HuR (left) and detailed section around the reef (right). Intervals with prevailing carbonates are shaded. Horizons with detailed mollusc-sampling are marked. The left section represents grain sizes $(M=$ mudstone, Fs = fine sand, Ms = medium sand, $\mathrm{Cs}=$ coarse sand, $\mathrm{Cg}=$ conglomerate, $\mathrm{B}=$ boundstone), whereas the right section is a weathering profile.

marck). Although typical of Maastrichtian strata in Argentina, the biostratigraphic potential of these taxa is still unexplored and thus of limited use for a chronostratigraphic assignment. We have thus performed Sr-isotope dating of the best preserved calcitic bivalve shells available. The first value comes from a bivalve in a silty claystone immediately above the reef (HuR B1, Fig. 3), which is indicative of an earliest Maastrichtian age (Fig. 4). The only additional Sr date in $\mathrm{HuR}$ is from HuR 5, six meters above the reef, which still suggests an early Maastrichtian age. Additional data from higher up in the $\mathrm{Hu}$ section confirm a Late Maastrichtian age suggesting that our sections span the entire Maastrichtian (Figs 3, 4). Following Casadío (1998), the Danian is marked by the first occurrence of Pycnodonte burckhardti (Böhm), which is approximately coincident with the base of the massive carbonates of the Roca Formation (Fig. 3) as already suggested by Ramos (1981) on the basis of the megafauna content and its correlation with the microfaunal associations of Bertels (1968, 1969a, 1969b, 1970). 


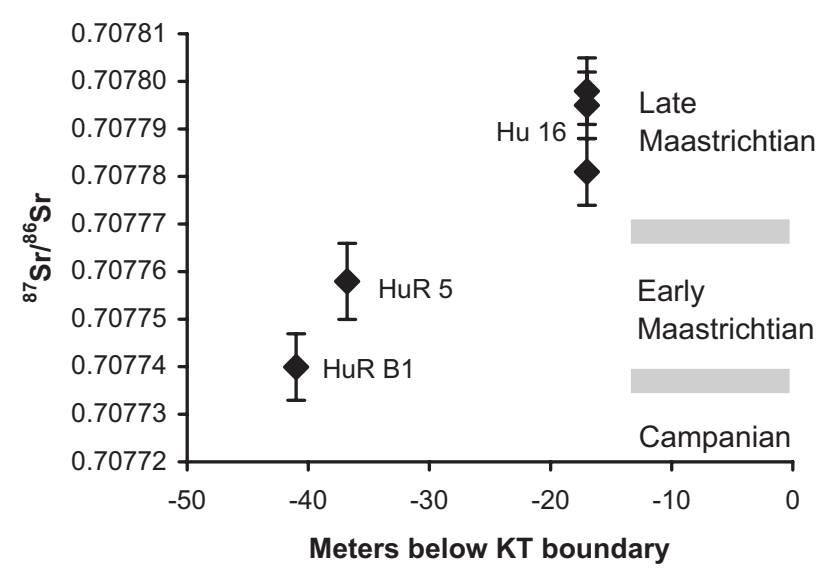

Fig. 4. Strontium isotope data (normalized to USGS EN-1 mean value and corrected for deviation from the mean value) of bivalve shells in the Huantraico area plotted against distance from the Cretaceous-Paleogene boundary (KT), defined by the first occurrence of Pycnodonte burckhardti. Grey bars indicate positions of substage boundaries according to the lookup-tables of McArthur (pers. comm., 2005).

\section{Description of microbial mound}

The reef is located at $37^{\circ} 32^{\prime} 18^{\prime \prime} \mathrm{S}, 69^{\circ} 52^{\prime} 28^{\prime \prime} \mathrm{W}$ at $1190 \mathrm{~m} \mathrm{NN}$. The reef body is clearly visible as a three-dimensional structure (Fig. 5). The reef grew on top of greenish, cross-bedded conglomerates. It is separated from the conglomerates by a thin marl layer. The reef structure is flanked and overlain by serpulid packstones, which are described in the next section. Macroscopically the reef boundaries appear sharp (Fig. 5D, E) but in thin section, the boundary is marked by increasing interfingering with overlying serpulid packstones (Fig. 6A, C).

The reef has a lateral extent of $200 \mathrm{~cm}$ and a maximum thickness of $80 \mathrm{~cm}$. The reef's boundaries are highly irregular (Fig. 5). The reef is highly variable in composition. Peloidal grainstones and packstones are most common, stromatolitic crusts and massive cements are next in relative abundance followed by micritic thrombolites (with some bafflestones). We have accordingly separated three main microfacies types, which can be separated into six subfacies.

Peloidal facies (Figs 6F, 7A, B). Subfacies A. The dominant subfacies type is a fecal pellet limestone. Pellets are elliptical to rod-shaped and usually densely packed. The pellets form grainstones (Fig. 7A) and packstones (Fig. 7B). The matrix in the packstones is a clotted micrite. Rod-shaped pellets reach up to $1.5 \mathrm{~mm}$ in length. Although these larger pellets are clearly of fecal origin, there are also much smaller peloids. These smaller peloids are partially of fecal origin but there is also evidence of microbial peloids with clotted structure and irregular boundaries. Some pellets are broken, probably due to shrinkage and compaction. Smaller peloids are locally common and form another subfacies type (subfacies B), which is associated with all other facies types, but most commonly with thick fibrous cement crusts (Fig. 7C).

Stromatolite-cement-framestone (Figs 6C, E, 7D-F). Subfacies A. Densely laminated stromatolite crusts and massive cements dominate this subfacies. Stromatolites are exclusively non-skeletal (sensu Riding, 2000) and nucleate on limestone fragments (Fig. 7D). Subfacies B. More common than laminated stromatolites are indistinctly laminated, dense cement crusts. These crusts often grow on stromatolites. Remnants of laminae in the crusts associated with stromatolites may suggest that the crusts are diagenetically altered stromatolites but some crusts show relics of bundled fibrous calcite crystals (Fig. 7E), which are known from inorganic marine cements and calcareous sinter (Flügel 2004; Pentecost 2005). Thick cement crusts also line dissolution cavities in the fecal pellet facies (Fig. 6F) or occur at the reef top (Figs 5F, 6C). These crusts are often massive without distinct internal structures and are best interpreted as sinter crusts formed by re-precipitation of dissolved carbonate.

Microcrystalline facies (Figs 6A, D, 7G, $\mathrm{H})$. This facies type has two distinct end members (subfacies). Subfacies A is most common and can be described as a dense calcified microbial thrombolite sensu Riding (2000) (Figs 6D, 7G). The thrombolite is rich in small voids filled with blocky spar (birdseyes). There is a continuous transition of the microbial peloid facies (Subfacies 1B) into dense thrombolites. Subfacies B is a dense micrite with thin disarticulated ostracod shells (Fig. 6A, D). Small, branching calcitic tubes in this subfacies (Fig. 6D) are reminiscent of the Oligocene-Miocene Cladophorites, interpreted to be a non-skeletal freshwater green alga (Reis 1926; Riding 1979; Arp 1995; Freytet 1997, 2000). Another type of alga forms dense aggregations of spherical bodies. The dimensions of these structures, their patchy occurrence, their association with micrite, and the diverse diagenetic alterations of wall structures permit an assignment to Chlorellopsis coloniata Reis (Fig. $7 \mathrm{H})$. Although it remains to be proven that this species is a green alga related to modern Chlorella and several alternative assignments 

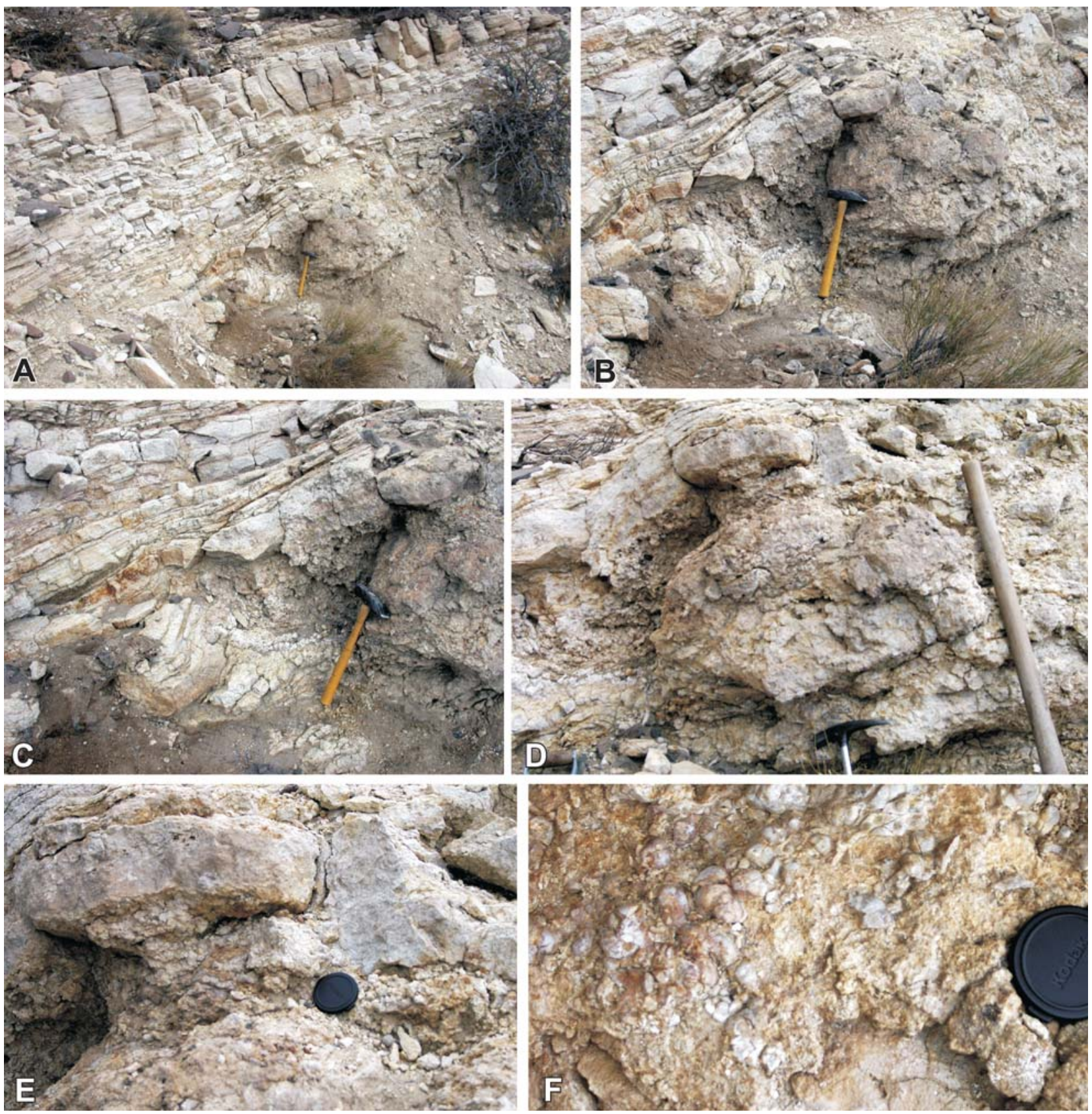

Fig. 5. Outcrop photographs of the microbial reef. $\mathbf{A}$ - Overview of outcrop approximately covering the detailed section of Fig. 3; B - Main reef body with capping grainstone-marl couplets; $\mathbf{C}$ - Flank of reef body with onlap structures; $\mathbf{D}-$ Detail of upper reef body; $\mathbf{E}$ - Upper contact of reef body with bedded serpulid packstones; $\mathbf{F}$ - Close-up of upper reef surface showing small sinter domes.

were suggested (Arp 1995; Freytet 1997), the currently favored assignment is indeed to the algae (Freytet 2000).
An additional facies occurs at the top of the reef. This is characterized by a fairly densely laminated micrite and microspar matrix with lenti-

Fig. 6. Thin section photographs of the microbial reef (overview of facies). $\mathbf{A}$ - Reef margin with micritic thrombolite clasts derived from the reef floating in a serpulid wackestone matrix. Note large serpulid tube (arrows) and bivalve shell (b); B - "Sickle-cell" limestone near top of reef. Microcrystalline sheets of inclusion-rich, fibrous cements spanning over lenticular voids; $\mathbf{C}$ - Sinter crust breccia with void filled by serpulid wackestone near reef top; $\mathbf{D}$ - Micritic reef core with large voids filled with vadose silt; dark grey $(\mathrm{m})$ is dense micrite with thin-shelled ostracods and Cladophorites-like structures (magnified in inset on the upper right, with ostracod shells), lighter grey portions (t) are thrombolitic micrite (see also Fig. 7G), fecal pellet packstone (p) and dense aggregations of Chlorellopsis (c) are also present; $\mathbf{E}$ - Brecciated stromatolite framestone overgrown by travertine crusts in upper part of reef; $\mathbf{F}$ - Reef base with large microspar-filled dissolution cavities lined with inclusion-rich sinter cement; overlain by fecal pellet grainstone. 

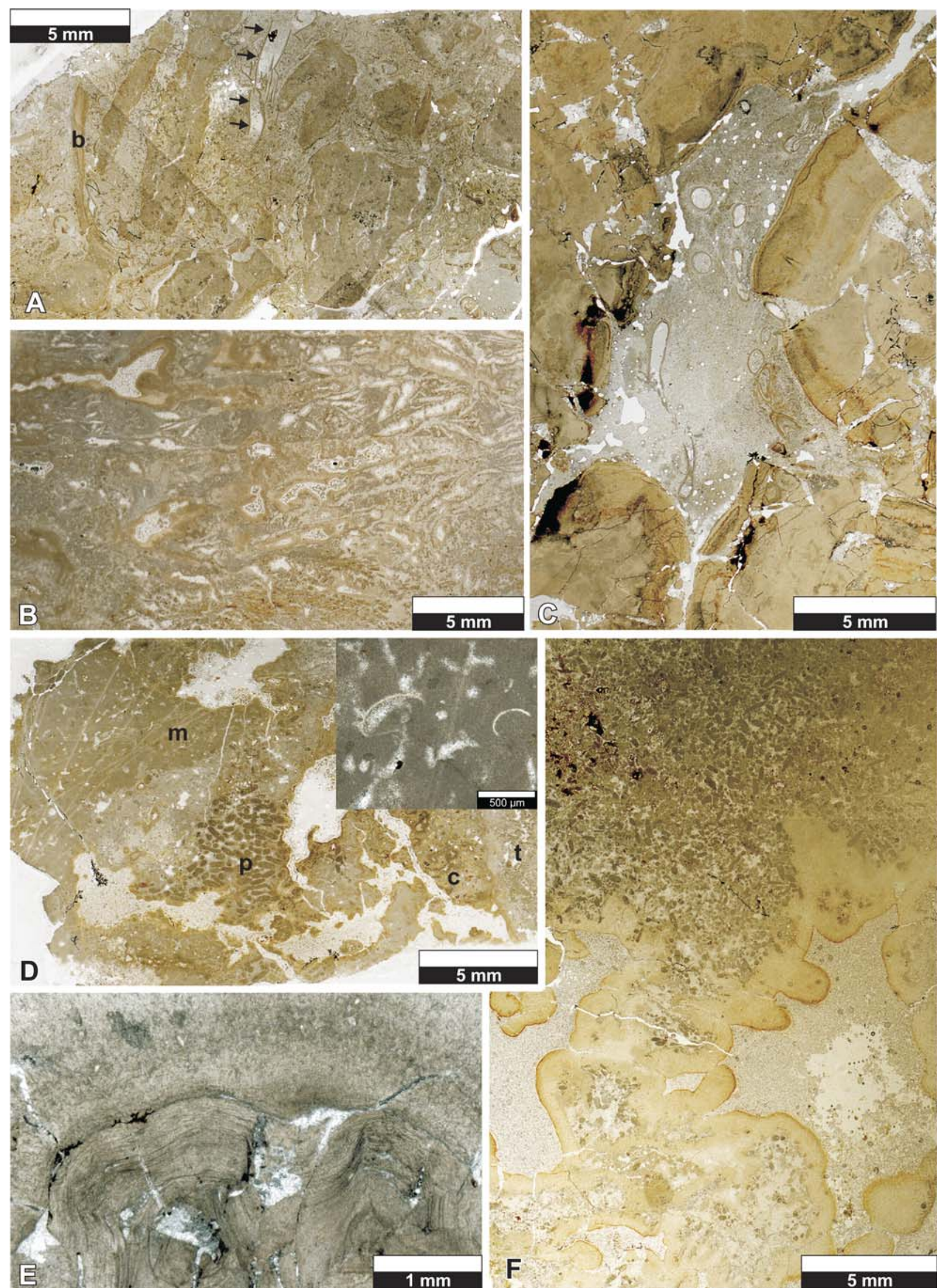

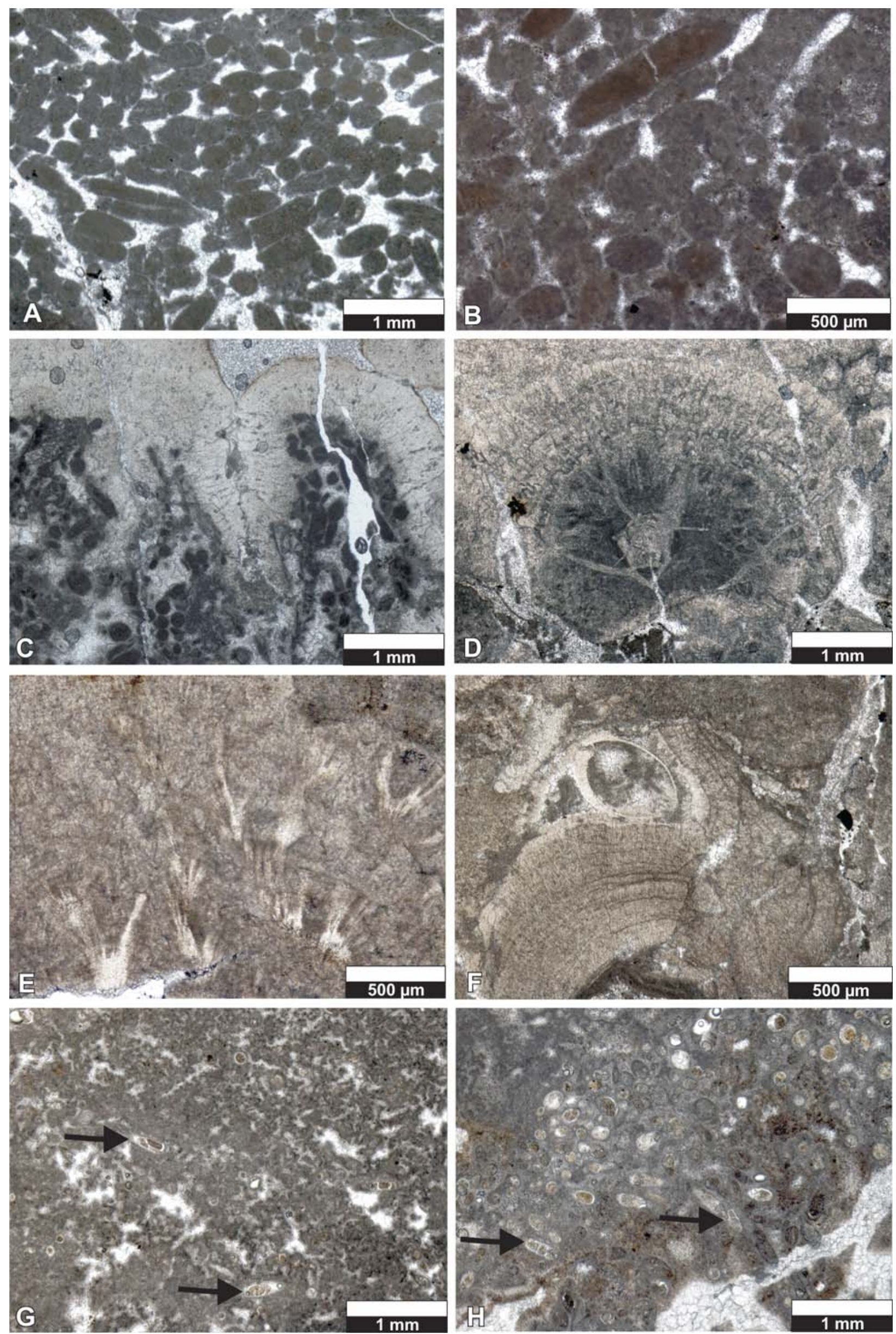
cular to sickle-cell-shaped voids, which are lined by thick sheets of inclusion-rich, fibrous cements (Fig. 6B). Limestones of very similar aspect have been described from the Ries Lake as "sicklecell" limestones (Riding 1979; Arp 1995; Pache et al. 2001).

A distinct facies zonation is absent in the reef. There is a weak pattern of more common stromatolitic crusts at the base and top of the reef structure and prevailing peloids and thrombolitic micrite in the reef core. Skeletal fossils are very rare in the reef. The only examples are ostracods and small foraminifers. Ostracods occur as thickshelled articulated forms (Fig. 7F) and thinshelled disarticulated morphotypes (Fig. 6D). Foraminifers were observed in thrombolitic facies and associated with Chlorellopsis masses. They are exclusively benthic rotaliids (hyaline tests). Uniserial, biserial and planispiral arrangements of chambers were observed (Fig. 7G, H). Bioerosion is apparently absent in the reef. Traces of bioerosion have only been found in the overlying grainstones.

Irregular voids occur in all facies. The voids are often lined by yellowish, calcitic sinter crusts and filled with blocky spar (Figs 6B, 7G). Breccia fabrics are common in the reef (Figs 6C, E, 7F). In the reef interior, the cavities between fragments are filled with large calcite-block cement (up to $0.4 \mathrm{~mm}$ crystal diameter), but near the reef top the cavities are filled with serpulid wackestones of the overlying serpulid limestones (Fig. 6C).

\section{Interpretation of reef fabrics}

The reef is best described as a thrombolite-stromatolite-cement reef. The fecal pellet facies, although widespread within the reef, is unlikely to have contributed to reef construction but was probably concentrated in reef cavities. Very similar pellets were interpreted by Arp (1995) as fecal pellets of Artemia, a common crustacean in modern saline lakes. An identical facies in the Ries Lake is limited to marginal parts of seepage-related tufa mounds (Arp 1995).
Most of the voids, especially the smaller ones, are likely to stem from degassing of decaying microbial mats. Larger cavities are formed by dissolution or brecciation. Dissolution cavities were formed synsedimentarily during breaks of reef growth and at later diagenetic stages. The former are lined by sinter crusts and filled with crystal silt (Fig. 6F), the latter lack cement linings (Fig. 6D).

All breccias can be interpreted to represent collapse breccias, formed within the reef. The large clast sizes, angularity and poor sorting support this interpretation. The common dissolution cavities, sinter crusts and calcitic crystal silts indicate a strong meteoric overprint of the reef structure. A pedogenic overprint as seen in the lacustrine Ries bioherms (Arp 1995), however, is not observed in our reef.

Due to poor exposure, the lateral contact between the reef and bedded limestones is not clear, but it appears that the bedded limestones pinch out against the reef and were thus deposited subsequent to reef growth. The interfingering of thrombolite and serpulid limestone at the reef top was probably caused by reworking. The observation of serpulid limestone in reef cavities suggests that these were still open when the bedded limestones were deposited.

\section{Microfacies of overlying limestones}

Thin sections were studied from two limestone intervals (HuR 2 and HuR 3). HuR 2 is from the limestone package immediately above the reef. These often thin-bedded limestones are serpulid wackestones and packstones with a microspar matrix (Fig. 8). The microspar matrix has a uniform crystal size and equant crystal shapes. Cavities within fossils are filled with drusy mosaic cement. The serpulids are strongly fragmented, both due to synsedimentary transportation and compaction (Fig. 8A, B, D). Except for the most basal limestone layers, bryozoans are common (Fig. 8A, C). Serpulids appear to be of low diversity, but several different morphotypes of bryozoans can be recognized. A point-count analysis of

Fig. 7. Thin section photographs of the microbial reef. $\mathbf{A}$ - Fecal pellet grainstone without micrite matrix (reef core); $\mathbf{B}-$ Fecal pellet packstone with common clotted micrite in matrix (reef core); $\mathbf{C}$ - Microbial peloids with overgrowth of travertine crusts and recrystallized microspar matrix (upper part of reef); $\mathbf{D}$-Stromatolite framestone with nucleation center and fine-scale lamination (upper part of reef); $\mathbf{E}$ - Close-up of cement-framestone precipitated on stromatolitic framestone with relics of fibrous outward spreading calcite crystals (= splays, upper part of reef); $\mathbf{F}$ - Stromatolitic breccia with articulated ostracod in thrombolitic cavity (upper part of reef); $\mathbf{G}$ - Thrombolite with clotted mesofabric and voids. Note small benthic foraminifers (arrows) and birdseyes; magnification of Fig. 6D; $\mathbf{H}$ - dense aggregation of Chlorellopsis coloniata Reis associated with small rotaliid foraminifers (arrows); magnification of Fig. 6D. 

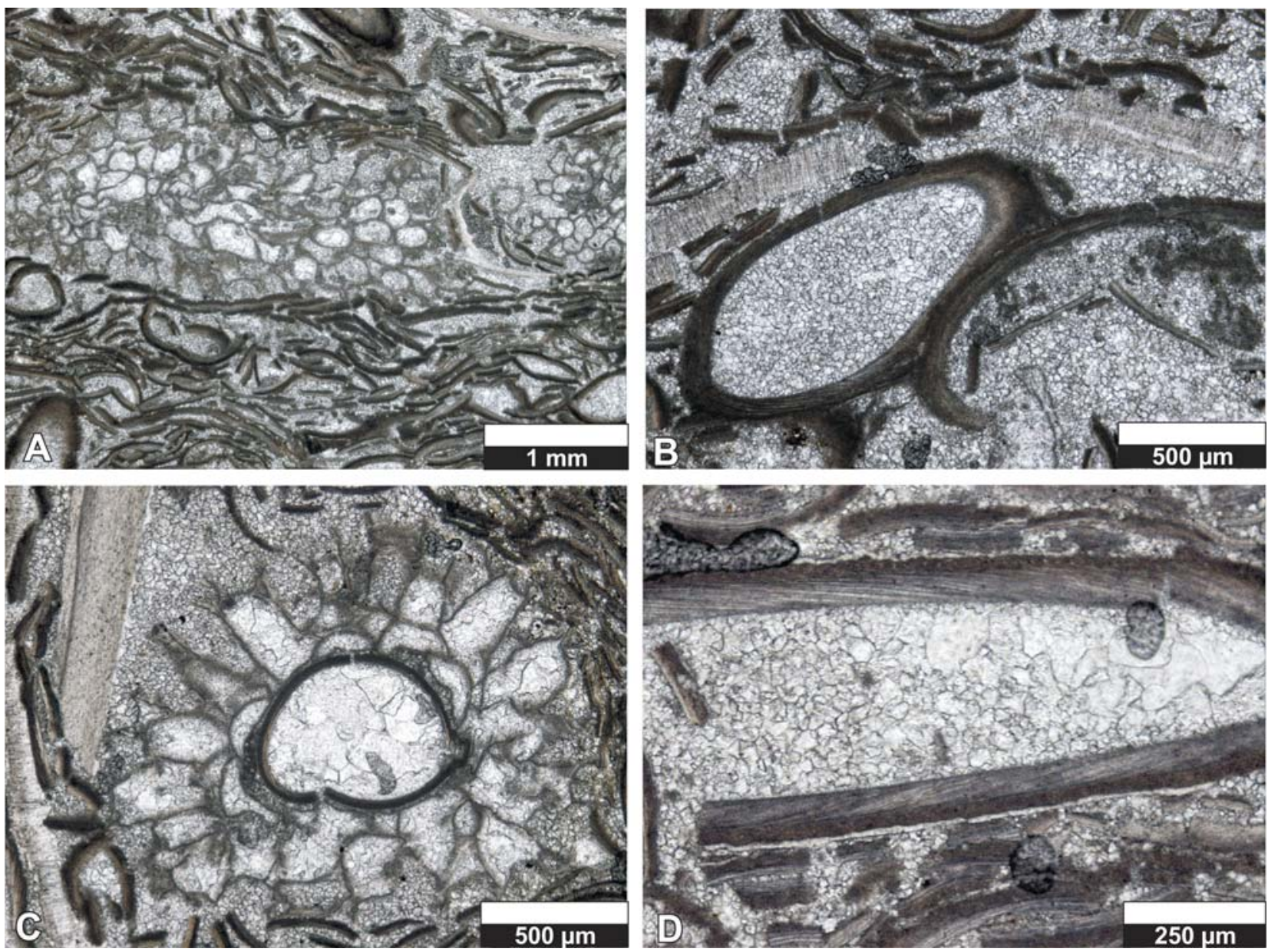

Fig. 8. Thin section photographs of serpulid packstones overlying and flanking the reef (HuR 2). A - Large bryozoan colony in serpulid packstone. Serpulids are crushed due to compaction; $\mathbf{B}$ - Attached serpulid tubes; these structures suggest that the abundance of serpulids derives from reworked serpulid patch reefs; $\mathbf{C}$ - Well preserved bryozoan cross-section in serpulid packstone; note bivalve shell at left; $\mathbf{D}$ - Large fragment of serpulid showing characteristic double-layer microstructure.

three thin sections from two different beds in this lithofacies (558 total counts) yields the following results (errors refer to binomial standard errors): Microspar matrix $53 \pm 2 \%$, serpulids $38 \pm 2 \%$, bryozoans $7 \pm 1 \%$, bivalves $1 \%$. If uncrushed, serpulids are often attached (Fig. $8 \mathrm{~B}$ ) suggesting an original colonial mode of growth and subsequent reworking by wave-action.

HuR 3 is from the top of the thick limestone bed (Fig. 3). This is an intraclast-ooid grainstone with common calcareous algae, gastropods, serpulids, bryozoans and some ostracods and bivalves. A wide spectrum of carbonate grains is present: abundant ooids and intraclasts, common skeletal grains, and rare peloids, cortoids, and pisoids (counted together with ooids). The conspicuous ooids usually have fossils and/or intraclasts as nuclei. The fossil-bearing intraclasts are usually micritic and well-rounded. This indicates that they were lithified and transported prior to the precipitation of oolitic rims. Multiple reworking is indicated by broken bioclasts, broken intraclasts with fossils, and broken ooids (Fig. 9A). The algal flora consists of poorly preserved dasycladaceans (Fig. 9A, C, E, F) and charophycean gyrogonites (Fig. 9B). The only identifiable algae can be assigned to Jodotella (Fig. 9C, F), a dasyclad common in Maastrichtian and Paleocene tropical and subtropical carbonate platforms (Moussavian \& Vecsei 1995; Parente 1997). Additional bioclasts are common serpulids, gastropods and bryozoans (Fig. 9A) and rare bivalves, ostracods and foraminifers (both planktonic and benthic, only occurring in intraclasts). One small fragment of a coral was also found (Fig. 9D). The point-count analysis of three thin sections (554 total counts, double counts for fossils in other grain types) yields: Cement $24 \pm 2 \%$, intraclasts $22 \pm 2 \%$, ooids $17 \pm 2 \%$, calcareous algae $12 \pm 1 \%$, serpulids $9 \pm 1 \%$, bryozoans $5 \pm 1 \%$, gastropods $5 \pm 1 \%$, and cyanophyceans(?) $2 \pm 1 \%$. The other components with $1 \%$ or less 

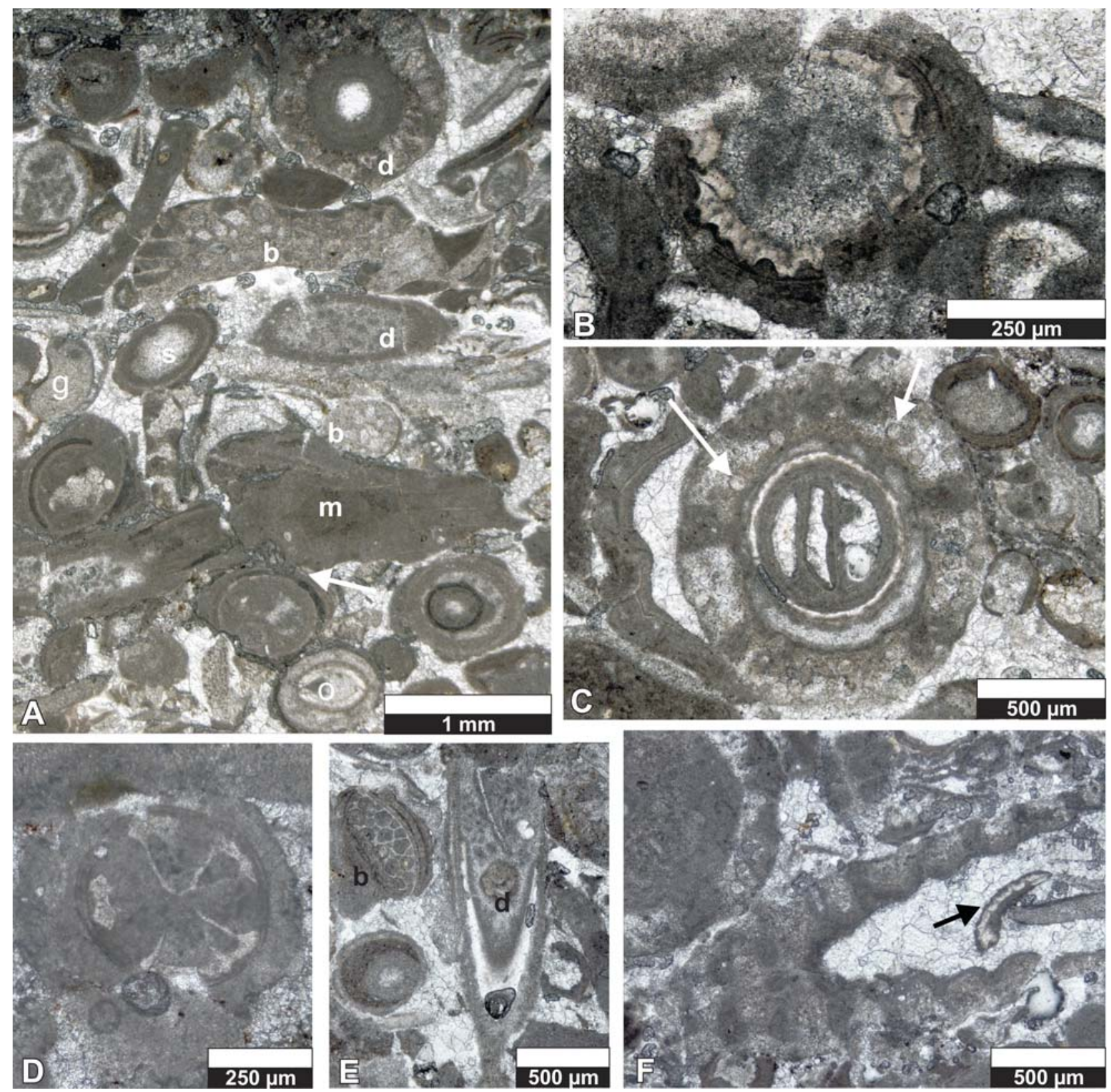

Fig. 9. Thin section photographs of high-energy limestones two meters above the microbial reef (HuR 3). A - Oolitic grainstones with micritic intraclasts $(\mathrm{m})$ and diverse bioclasts, partially coated by oolitic rims: $\mathrm{d}$ - dasycladaceans, b - bryozoans, $\mathrm{g}$ - gastropod, o - ostracod, s - serpulid. Note stylolitic grain contacts (arrow); B - Charophyte gyrogonite in densely laminated ooid; C - Cross section of dasycladacean alga (Jodotella sp.) with structures interpreted as reproductive organs (cysts) in laterals (arrows). The thallus hosts an unidentified organism (gastropod?) with stromatolitic encrustations; D - Partially preserved corallite of a scleractinian coral; $\mathbf{E}$ - Tangential section of poorly preserved, indeterminate dasycladacean algae (d); note broken ooid with bryozoan in core (b); F - Slightly oblique longitudinal section of Jodotella; note charophyte gyrogonite fragment in thallus (arrow).

of thin section area are cortoids, bivalves, ostracods, peloids and foraminifers.

\section{Discussion}

Our discussion focuses on two aspects: (1) environmental setting of the reef and overlying limestones; and (2) paleoclimatic significance of grain associations.

\section{Environmental setting}

Some specific environmental conditions must have been present to permit reef growth, because otherwise grazing pressure would be expected to preclude the formation of a three dimensional microbial structure. A shallow-water setting is indicated by the common structures inferred to represent green algae. As lacustrine to estuarine conditions prevail in the Loncoche Formation below and normal marine conditions 
are evident in the higher Roca Formation, the potential salinity control on reef growth is a key question. The inventory of microbial structures and algal morphotypes in the reef is otherwise largely known from Maastrichtian to Miocene freshwater settings (Rouchy et al. 1993; Camoin et al. 1997; Arp 1995; Freytet 1997, 2000). The "sickle-cell" facies near the reef top (Fig. 6B) is thus far only known from spring mounds in highly alkaline lakes (Arp et al. 1998; Pache et al. 2001). This fabric is thought to be indicative of secondary $\mathrm{Ca}^{2}+$ release by decarboxylation of biofilm exopolymers, which leads to precipitation of cements in lenticular shrinkage voids because the released $\mathrm{CO}_{2}$ is buffered by soda lake bulk phases (Arp et al. 1998). As ostracods occur in virtually all aquatic environments, the few ostracods in the reef are not useful for constraining salinity.

However, the small benthic foraminifers (Fig. 7G, H) suggest at least some influx of marine water. Although modern foraminifers are known from freshwater environments and are even thought to have repeatedly colonized freshwater environments in the geological past (Hedberg 1934; Holzmann et al. 2003), the great majority of mineralized (fossilizable) foraminifers is clearly marine (Murray 1991). Rotaliid foraminifers have also been documented from ancient lacustrine settings (Arp 1995; Rouchy et al. 1993; Camoin et al. 1997), but their origin remains difficult to explain. Based on the occurrence in only a single level, Arp (1995) favors the interpretation of birds having transported foraminifers into the Miocene Ries lake. Rouchy et al. (1993), however, argue in favor of a broader salinity tolerance of benthic foraminifers than usually accepted.

Stable isotope analyses $(\mathrm{C}, \mathrm{O})$ were only performed higher up in the normal marine portion of the investigated sections. These values show a great variance and strongly negative values, possibly due to diagenetic overprint. We therefore refrained from using carbon and oxygen isotopes in the reef horizon to interpret salinities.

In summary, most of the limited evidence from the reef alone would indicate a alkaline freshwater, probably lacustrine, rather than a marine setting. However, our dataset used for comparison (see references above) is strongly biased towards freshwater settings, because no similar Late Mesozoic-Cenozoic structures have been described from undisputed shallow marine environments. The geological context, however, does not suggest a lacustrine setting. The cross-bedded sands below the reef were likely deposited in an estuarine environment and the limestones above the reef are marine. The bedded limestones onlapping the reef limestone (HuR 2) indicate brackish marine conditions based on their fossil content (serpulids and bryozoans). The observations that pockets within the reef and immediately above the reef only contain serpulids and bivalves and are only accompanied by bryozoans above, might indicate a sequence from mesohaline to brachyhaline within the HuR 2 package applying the schema of Flügel (2004: fig. 12.11). Although both serpulids and bryozoans tolerate salinity fluctuations, they are indicative of marine deposits (Smith 1995; Flügel 2004). Yet the near absence of other skeletal bioclasts suggests harsh environmental conditions, perhaps due to strong salinity fluctuations.

In HuR 3, a shoreface setting is suggested by hummocky-cross stratification. The mixture of organisms preferring normal marine settings (bryozoans and scleractinian coral), organisms more typical of hyposaline and hypersaline conditions (serpulids, dasycladaceans) and organisms with a preference for brackish water and freshwater (charophyceans) suggests both a heterogeneous source of the bioclasts and a variable salinity in the hinterland. In none of the three limestone intervals studied by us, echinoderms or coralline algae were found. The absence of these good tracers of normal salinities (Flügel 2004) supports the view of a brackish water setting at least up to HuR 3. The first sample with fauna indicative of normal salinity (diverse marine bivalves, sea urchins) is HuR B1 from two meters above the reef.

In sum, the geological context suggests a transgressive sequence from oligohaline to euhaline conditions. Therefore, a brackish-water marginal marine setting rather than a freshwater lacustrine setting might be suggested for the microbial reef at Huantraico.

\section{Paleoclimatic significance}

The calculated paleolatitude of our section is roughly $38^{\circ} \mathrm{S}$ for the Maastrichtian using Scotese's rotation file (pers. comm. 2001). With modern latitudinal temperature gradients, we would expect temperate water carbonates to be deposited, when siliciclastic background sedimentation is low. Since early Maastrichtian temperature gradients were apparently lower than today (Frakes 1999), our site could still yield tropical 
Table 1

Tropical (T) versus non-tropical (NT) features of the limestones overlying the microbial reef applying a selection of the criteria of Flügel (2004).

\begin{tabular}{llll}
\hline Attribute & $\begin{array}{l}\text { Observation in Roca } \\
\text { Formation }\end{array}$ & $\begin{array}{l}\text { Typical of tropical (T) or } \\
\text { non-tropical (NT) carbonates }\end{array}$ & Remarks \\
\hline $\begin{array}{l}\text { Biodegradation } \\
\text { Aggregate Grains }\end{array}$ & Weak & $\mathrm{T}$ & usually stronger in NT \\
Ooids & Rare & $\mathrm{NT}$ & \\
Peloids & Common & $\mathrm{T}$ & rare to absent in NT \\
Intra-/Lithoclasts & Common & $\mathrm{T}$ & more common in T \\
Calcareous green algae & Common & $\mathrm{T}$ & \\
Stromatolites & Common & $\mathrm{T}$ & more common in NT \\
Bryozoans & Common & $\mathrm{TT}$ &
\end{tabular}

carbonates. Microbial reefs have a strong preference for low latitudes and, by inference, to warm water temperatures through the entire Phanerozoic (Kiessling 2001). This statistical approach alone, however, is of limited use for a paleoclimatic interpretation of the carbonate sequence.

The skeletal grain assemblages in the non-reefal limestones give a confusing picture (Table 1 ) not fitting any of the criteria and grain association types of Flügel (2004: table 2.2 and box 12.9). The difficulty to assign our carbonates to published types of grain associations is mostly due to the absence of coralline red algae and echinoderms, which are often used in the characterization of carbonate grain associations. The paleoclimatic interpretation is also problematic with the more simplified criteria of James (1997). The grain association in HuR 2 represents a pure heterozoan association sensu James (1997) and would thus be indicative of non-tropical carbonates. In contrast, there is a photozoan assemblage in HuR 3, especially indicated by the abundance of dasycladacean algae and ooids. The association of this tropical assemblage with common bryozoans and serpulids is confusing at first glance but can be explained by multiple sources of the skeletal grains and the inshore setting (James 1997). However, if applying the published criteria literally to our section, we would get a picture of tropical reef growth succeeded by cool-water limestone deposition, which in turn is replaced by tropical carbonates. These strong climatic changes appear unlikely given the just two meters of section. The mosaic of carbonate grain associations in the section is probably best explained by the long term salinity trend. Salinity changes have long been known to obscure the paleoclimatic potential of modern shelf carbonates (Lees 1975) and from the large range of other possible factors (Pomar et al. 2004), salinity appears to be indeed the dominant factor in our section.

\section{Conclusions}

We describe a small thrombolite-stromatolitecement reef which probably grew under oligohaline marginal marine conditions during a Maastrichtian regional transgression. Reef growth was likely governed by low siliciclastic sedimentation, reduced salinity, high alkalinity and warm temperatures. Although difficult to prove at this stage, reef growth seems to also have been governed by calcium-rich freshwater influx favoring the precipitation of carbonate. We have found one of the apparently rare microbial reefs of latest Cretaceous age, which did not originate in a lacustrine setting. A more intensive search for microbial mounds in the Late Cretaceous and Cenozoic, however, may quickly change this picture not only for brackish-water settings but also in normal marine environments as already suggested by Camoin (1995).

Microfacies analyses of the overlying bedded limestones underline the sensitivity of carbonate grain associations to salinity changes. The gradual increase of salinity in the basal Roca Formation led to a fluctuating paleoclimatic aspect of grain associations where tropical carbonates would be expected from paleogeographic and paleoclimatic reconstructions. The unique association of common serpulids and bryozoans with common dasycladaceans and ooids in the limestones overlying the reef calls for more work on the paleoclimatic potential of ancient limestones deposited under variable salinities.

\section{Acknowledgements}

We thank Silvio Casadio for pointing out the Huantraico region for our field campaign on the end-Cretaceous mass extinction. Ioan Bucur helped with the identification of the algae. Two anonymous reviewers provided valuable comments, which helped to improve the paper. Sylvia Salzmann prepared the thin sections. This study was supported by the DFG (Ki 806/1-1) and the Antorchas Foundation. 


\section{References}

Arp, G. 1995. Lacustrine bioherms, spring mounds, and marginal carbonates of the Ries-Impact-Crater (Miocene, Southern Germany). - Facies 33: 35-90.

Arp, G., Hofmann, J. \& Reitner, J. 1998. Microbial fabric formation in spring mounds ("Microbialites") of alkaline salt lakes in the Badain Jaran Sand Sea, PR China. - Palaios 13: $581-592$.

Arp, G., Reimer, A. \& Reitner, J. 2003. Microbialite formation in seawater of increased alkalinity, Satonda crater lake, Indonesia. - Journal of Sedimentary Research 73: 105-127.

Barrio, C. A. 1990. Late Cretaceous-Early Tertiary sedimentation in a semi-arid foreland basin (Neuquén Basin, western Argentina). - Sedimentary Geology 66: 255-275.

- 1991. Controles en la sedimentación de cuencas foreland. El ejemplo del Grupo Malargüe (Campaniano-Paleoceno) en la cuenca Neuquina, Argentina. - 6 Congreso Geológico Chileno, Resúmenes Expandidos: 597-601.

Bertels, A. 1968. Micropaleontología y estratigrafía del límite Cretácico-Terciario en Huantraico (Provincia de Neuquén). Ostracoda, Parte I. - Ameghiniana 5: 279-298.

- 1969a. Estratigrafía del límite Cretácico-Terciario en Patagonia septentrional. - Revista de la Asociación Geológica Argentina 24: 41-54.

- 1969b. Micropaleontología y estratigrafía del límite Cretácico-Terciario en Huantrai-co (Provincia de Neuquén). Ostracoda, Parte II. - Ameghiniana 6: 253-278.

- 1970. Los foraminíferos planctónicos de la cuenca Cretácica-Terciaria en Patagonia Septentrional (Argentina), con consideraciones sobre la estratigrafía del Fortín General Roca (Provincia de Río Negro). - Ameghiniana 7: $1-47$.

- 1975. Ostracode ecology during the Upper Cretaceous and Cenozoic in Argentina. - Bulletins of American Paleontology 65: 318-351.

Camacho, H. H. 1968. Acerca de la megafauna del Cretácico Superior de Huantraico, Provincia del Neuquén (Argentina). - Ameghiniana 5: 321-332.

Camoin, G. F. 1995. Nature and origin of Late Cretaceous mud-mounds, north Africa. In Monty, C. L. V., Bosence, D. W. J., Bridges, P. H. \& Pratt, B. R. (eds.) Carbonate Mud-Mounds - Their Origin and Evolution, Special Publications of the International Association of Sedimentologists 23: 385-400, Oxford.

Camoin, G., Casanova, J., Rouchy, J.-M., Blanc-Valleron, M. M. \& Deconinck, J.-F. 1997. Environmental controls on perennial and ephemeral carbonate lakes: the central palaeo-Andean Basin of Bolivia during Late Cretaceous to early Tertiary times. - Sedimentary Geology 113: 1-26.

Casadío, S. 1998. Las ostras del límite Cretácico-Paleógeno de la cuenca Neuquina (Argentina). Su importancia bioestratigraáfica y paleobiogeográfica. - Ameghiniana 35: 449-471.

Digregorio, J. H. \& Uliana, M. A. 1980. Cuenca Neuquina Geología Regional Argentina II: 985-1032, Academia Nacional de Ciencias, Córdoba.

Feldmann, M. \& McKenzie, J. A. 1998. Stromatolite-thrombolite associations in a modern environment, Lee Stocking Island, Bahamas. - Palaios 13: 201-212.

Flügel, E. 2004. Microfacies of carbonate rocks: analysis, interpretation and application. 976 pp, Springer, Berlin.

Frakes, L. A. 1999. Estimating the global thermal state from Cretaceous sea surface and continental temperature data. In Barrera, E. \& Johnson, C. C. (eds) Evolution of the Cretaceous Ocean-Climate System, 332: 49-57, Geological Society of America Special Paper, Boulder.

Freytet, P. 1997. Non marine Permian to Holocene algae from France and adjacent countries (Part I). - Annales de Paléontologie 83: 289-332.
- 2000. Distribution and palaeoecology of non marine algae and stromatolites: II, the Limagne of Allier Oligo-Miocene lake (central France). - Annales de Paléontologie 86: $3-57$.

Gautret, P., Camoin, G., Golubic, S. \& Sprachta, S. 2004. Biochemical control of calcium carbonate precipitation in modern lagoonal microbialites, Tikehau atoll, French Polynesia. - Journal of Sedimentary Research 74: 462478 .

Hedberg, H. D. 1934. Some recent and fossil brackish to freshwater foraminifera. - Journal of Paleontology 8: 469-476.

Holzmann, M., Habura, A., Giles, H., Bowser, S. S. \& Pawlowski, J. 2003. Freshwater foraminiferans revealed by analysis of environmental DNA Samples. - Journal of Eukaryotic Microbiology 50: 135-139.

James, N. P. 1997. The cool-water carbonate depositional realm. In James, N. P. \& Clarke, J. A. D. (eds.) Cool-Water Carbonates 56: 1-20, SEPM Special Publication, Tulsa.

Kadolsky, D. \& Koch, R. 1988. Pseudoriffe im Landschneckenkalk und in den tieferen Oberen Cerithienschichten (Oberoligozän) des Mainzer Beckens. - Geologisches Jahrbuch A 110: 135-163.

Kiessling, W. 2001. Paleoclimatic significance of Phanerozoic reefs. - Geology 29: 751-754.

- 2002. Secular variations in the Phanerozoic reef ecosystem. In Kiessling, W., Flügel, E. \& Golonka, J. (eds) Phanerozoic Reef Patterns 72: 625-690, SEPM Special Publications, Tulsa.

Kiessling, W. \& Flügel, E. 2002. Paleoreefs - a database on Phanerozoic reefs. In Kiessling, W., Flügel, E. \& Golonka, J. (eds) Phanerozoic Reef Patterns 72: 77-92, SEPM Special Publications, Tulsa.

Laval, B., Cady, S. L., Pollack, J. C., Mckay, C. P., Bird, J. S., Grotzinger, J. P., Ford, D. C. \& Bohm, H. R. 2000. Modern freshwater microbialite analogues for ancient dendritic reef structures. - Nature 407: 626-629.

Lees, A. 1975. Possible influence of salinity and temperature on modern shelf carbonate sedimentation. - Marine Geology 19: 159-198.

Moussavian, E. \& Vecsei, A. 1995. Paleocene reef sediments from the Maiella carbonate platform, Italy. - Facies 32: 213-222.

Murray, J. W. 1991. Ecology and paleontology of benthic foraninifera. 397 pp, Longman, Essex.

Pache, M., Reitner, J. \& Arp, G. 2001. Geochemical evidence for the formation of a large Miocene 'travertine' mound at a sublacustrine spring in a soda lake (Wallerstein Caste Rock, Nördlinger Ries, Germany). - Facies 45: 211-230.

Parente, M. 1997. Dasycladales from the Upper Maastrichtian of Salento Peninsula (Puglia, Southern Italy). Facies 36: 91-122.

Parma, S. G. \& Casadio, S. 2005. Upper Cretaceous-Paleocene echinoids from northern Patagonia, Argentina. Journal of Paleontology 79: 1072-1087.

Pentecost, A. 2005. Travertine. 445 pp, Springer, Heidelberg.

Pomar, L., Brandano, M. \& Westphal, H. 2004. Environmental factors influencing skeletal grain sediment associations: a critical review of Miocene examples from the western Mediterranean. - Sedimentology 51: 627-651.

Ramos, V. A. 1981. Descripción geológica de la hoja 33c, Los Chihuidos Norte, provincia del Neuquén. - Argentina, Servicio Geológico Nacional, Boletín 182: 1-103.

Reid, R. P., James, N. P., Macintyre, I. G., Dupraz, C. P. \& Burne, R. V. 2003. Shark Bay stromatolites: Microfabrics and reinterpretation of origins. - Facies 49: 299-324.

Reis, O. M. 1926. Zusammenfassung über die im Ries südlich von Nördlingen auftretenden Süßwasserkalke und ihre Entstehung. - Jahresberichte und Mitteilungen des oberrheinischen geologischen Vereins, Neue Folge 14: 176-190.

Reitner, J., Peckmann, J.r., Reimer, A., Schumann, G. \& Thiel, V. 2005. Methane-derived carbonate build-ups and 
associated microbial communities at cold seeps on the lower Crimean shelf (Black Sea). - Facies 51: 66-79.

Riding, R. 1979. Origin and diagenesis of lacustrine algal bioherms at the margin of the Ries crater, Upper Miocene, southern Germany. - Sedimentology 26: 645-680, 41 Figs.

- 2000. Microbial carbonates: The geological record of calcified bacterial-algal mats and biofilms. - Sedimentology 47 Supplement 1: 179-214.

- 2004. Reefal microbial carbonate abundance: comparisons with Phanerozoic metazoan diversity, mass extinction events, and seawater saturation state. - Geological Society of America Abstracts with Programs 36: 181.
Rouchy, J. M., Camoin, G., Casanova, J. \& Deconinck, J. F. 1993. The central palaeo-Andean basin of Bolivia (Potosi area) during the late Cretaceous and early Tertiary: reconstruction of ancient saline lakes using sedimentological, paleoecological and stable isotope records. - Palaeogeography, Palaeoclimatology, Palaeoecology 105: 179-198.

Smith, A. M. 1995. Paleoenvironmental interpretation using bryozoans: a review. In Bosence, D. W. J. \& Allison, P. A. (eds.) Geological Society of London Special Publications 83: 231-243, London.

Weaver, C. E. 1927. The Roca Fm. in Argentina. - American Journal of Science 5: 417-434. 